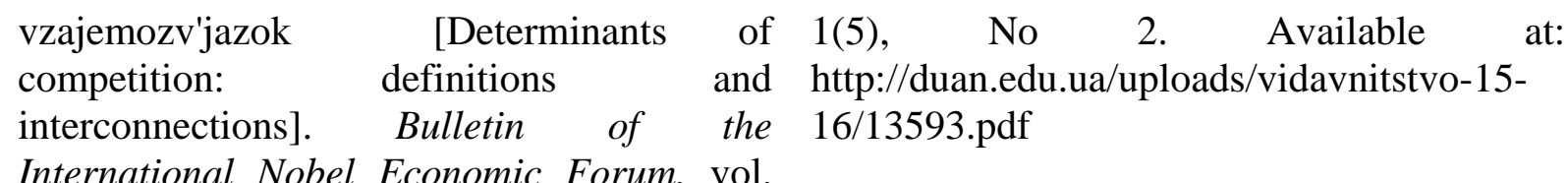

\title{
ФОРМУВАННЯ ОРГАНІЗАЦІЙНО-ЕКОНОМІЧНОГО МЕХАНІЗМУ УПРАВЛІННЯ КОНКУРЕНТНИМИ ПЕРЕВАГАМИ НА ПІДПРИЕМСТВАХ ЗАЛІЗНИЧНОГО ТРАНСПОРТУ
}

Каличева Н.Є., к.е.н., доцент (УкрДУЗТ)

\begin{abstract}
Стаття присвячена питанням формування організаційно-економічних підходів управління конкурентоспроможністю на підприємствах залізничного транспорту. Розкрито змістовне наповнення підходів до управління конкурентними перевагами в галузі. Визначений інструментарій забезпечення виконання організаційно-економічним механізмом управління конкурентними перевагами підприємств залізничного транспорту. Обгрунтовано сутність, структуру та роль організаційної та економічної складової управлінського механізму в умовах посилення конкуренції на внутрішньому та зовнішньому ринках транспортних послуг.

Ключові слова: залізничний транспорт,конкурентоспроможність, транспортна послуга, перевізний процес, управління, механізм, інструментарій

\section{ФОРМИРОВАНИЕ ОРГАНИЗАЦИОННО-ЭКОНОМИЧЕСКОГО МЕХАНИЗМА УПРАВЛЕНИЯ КОНКУРЕНТНЫМИ ПРЕИМУЩЕСТВАМИ НА ПРЕДПРИЯТИЯХ ЖЕЛЕЗНОДОРОЖНОГО ТРАНСПОРТА}

\author{
Каличева Н.Е., к.э.н, доцент (УкрГУЖТ)
}

Статья посвящена вопросам формирования организационно-экономических подходов управления конкурентоспособностью на предприятиях железнодорожного транспорта. Раскрыто содержательное наполнение подходов $к$ управлению конкурентными преимуществами в отрасли. Определенный инструментарий обеспечения выполнения организачионно-экономическим механизмом управления конкурентными преимуществами предприятий железнодорожного транспорта. Обоснованно сущность, структуру и роль организационной и экономической составляющей управленческого механизма в условиях усиления конкуренщии на внутреннем и внешнем рынках транспортных услуг.

Ключевые слова: жселезнодорожный транспорт, конкурентоспособность, транспортная услуга, перевозочный процесс, управление, механизм, инструментарий 


\title{
FORMATION OF THE ORGANIZATIONAL AND ECONOMIC MECHANISM OF MANAGEMENT OF COMPETITIVE ADVANTAGES AT THE ENTERPRISES OF RAILWAY TRANSPORT
}

\author{
Kalicheva N.E., candidate of economic sciences, associate professor (USURT)
}

The management mechanism is an integral part of the management system, resulting in an effective influence on a variety of factors, which leads to a certain result of the object of management. Focusing on the needs of the consumer, implementing an effective science and technology, innovation and market policy, the desire to update and apply innovations, recognition of social responsibility become the main factors that have a direct impact on the mechanism of enterprise management. For railway companies with a complex management structure, a special place in management is the need to integrate all economic, organizational and technical processes necessary to integrate into one whole all internal industry resources, enhance adaptability and competitiveness. Thus, changing approaches to enterprise management requires a thorough revision of the entire management system, changing the psychology of workers at all levels, improving their qualifications, changing the principles of forming a strategy for enterprise development and defining its goals, the structure of organization and management, the process of developing and adopting management decisions, work with personnel, approaches to assessing the effectiveness of the entire enterprise, its production units and services and workers.

Dynamic changes in the market environment, the struggle for the consumer through the creation of such a product, which he wants to get the consumer, the growth of competition leads to the need to revise all management activities of the enterprise. After all, management activities to date are one of the main factors in the effective functioning of an enterprise or company, and the formation of an effective organizational and economic management mechanism will promote productive management and ensure a high level of competitiveness. The key methods of organizational and economic management of the competitiveness of a modern enterprise include: the revitalization of investment and innovation activities, technical re-equipment; improvement of management in the field of finance and capital investments; development of measures on productive use of production, material and financial resources; improvement of personnel management and personnel motivation; introduction of an effective quality management system; use of methods of quality management of products or services; changing approaches to planning and diversifying the production process; review of accounting and cost analysis system; Improve marketing research by reviewing market research approaches; improvement of information support and digitalization of all possible managerial, organizational and production processes; the combination of all components of management activity in relation to the domestic and foreign policy of the enterprise.

The proposed approaches to the introduction of a management mechanism to ensure the competitiveness of railway companies enable them to keep their existing competitive positions and raise their level of competitiveness today and in the future. But measures aimed at increasing competitiveness will not be met unless the railways management clearly determines the strategy for the development of each component of the railway transport sector both in the current period and in the future.

Key words: railway transport, competitiveness, transport service, transportation process, management, mechanism, toolkit 
Постановка проблеми та ї зв'язки з науковими чи практичними завданнями. Механізм управління $\epsilon$ складовою системи управління, спричиняючи дієвий вплив на різноманітні фактори, що призводить до певного результату діяльності об'єкта управління. Орієнтація на потреби споживача, здійснення дієвої науковотехнічної, інноваційної та ринкової політики, потягу до оновлення та застосування нововведень, визнання соціальної відповідальності стають основними факторами, котрі мають прямий вплив на механізм управління підприємством.

Для підприємств залізничного транспорту, які мають складну управлінську структуру, особливе місце в управлінні займає необхідність інтеграції всіх економічних, організаційних та технічних процесів, що необхідно для з'єднання в одне ціле всіх внутрішніх ресурсів галузі, підсилення адаптивності та конкурентоспроможності.

\begin{tabular}{lll}
\multicolumn{1}{c}{ Ринкові } & відносини & сприяють \\
розвитку & достатньої & кількості
\end{tabular}
можливостей для плідного управління, проте складний економічний стан національної економіки, значний спад обсягів виробництва, відсутність транзитних перевезень, негативні тенденції в міжнародних відносинах та інші фактори зводять нанівець всі зусилля щодо підвищення якісних показників 3 управління в галузі. Саме тому, в цих складних економічних умовах, АТ «Укрзалізниця» має реалізувати сильне, цілеспрямоване управління для досягнення стабільного економічного стану. Ще один чинник, на який потрібно звернути увагу при зміні підходів до управління на підприємствах залізничного транспорту, $є$ те, що галузь у сучасних реаліях не може конструктивно змінити вплив зовнішнього середовища, тому при формуванні нового механізму управління потрібно більше уваги приділяти зміні умов внутрішнього середовища.
Таким чином, зміна підходів до управління підприємством потребує грунтовного перегляду всієї системи управління, зміни психології працівників всіх рівнів, підвищення їх кваліфікації, мають змінитися принципи формування стратегіï розвитку підприємства та визначення його цілей, структура організації та управління, сам процес розробки та прийняття управлінських рішень, робота 3 персоналом, підходи до оцінки ефективності роботи всього підприємства, його виробничих підрозділів і служб та робітників.

Аналіз останніх досліджсень $i$ публікацій. Аналізуючи дослідження конкурентоспроможності підприємств транспортної сфери, які представлені роботами Диканя В.Л., Данька М.I., Ейтутіса Д.Г., Гандельсмана Т.А., Бараша Ю.С., Обруч Г.В. та ін. [1-5], можна зробити висновок про існування проблем, пов'язаних із недостатнім опрацюванням підходів до формування системи організаційно-економічного управління конкурентоспроможністю підприємств залізничної галузі.

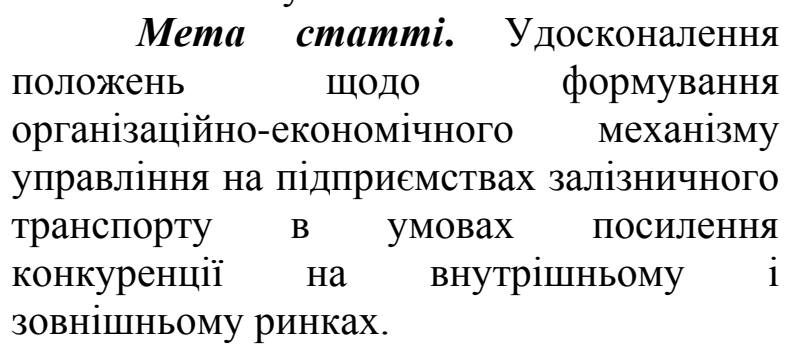

Викладення основного матеріалу дослідження. Сучасний процес функціонування економіки $є$ досить динамічним, що зумовлюється впливом зовнішнього середовища, a, отже, на діяльність підприємства постійно впливають такі групи чинників, як:

- соціально-економічні

встановлюють потрібні форми організації виробництва, праці та управління, зумовлюють потребу постійного розвитку виробничих сил;

- техніко-економічні - мають прямий вплив на зміну продуктивності праці, що зумовлює потребу в зміні схем 
організації виробництва, формування більш сучасних різновидів виробничих організацій, поглиблення господарських i науково-технічних зв'язків, тощо;

- регіональні, зокрема природні та кліматичні, - зумовлюють особливості формування та розвитку соціальної i виробничої інфраструктури, зміни в оплаті праці, забезпечення плідного використання природних багатств та охорони навколишнього середовища.

Під час ведення господарської діяльності підприємство відчуває на собі вплив всіх перерахованих вище чинників, але кожна $з$ груп має різну динаміку та по різному впливає на діяльність підприємства, яке прагне бути конкурентоспроможним на ринку [6]. Також воно має відповідати викликам зовнішнього середовища та на високому рівні задовольняти запити споживачів за рахунок:

- високої гнучкості виробництва для швидкої зміни асортименту послуг чи виробів;

- зміни технології виробництва із новою формою контролю, організації та поділу праці;

- створення виробів чи послуг високої якості та забезпечення додаткового після продажного сервісу;

- зміни структури витрат при здійсненні виробничого процесу;

- постійного аналізу

змін

зовнішнього середовища.

Таким чином, динамічні зміни в ринковому середовищі, боротьба за споживача шляхом створення такого товару, яким його бажає отримати споживач, зростання рівня конкуренції призводить до необхідності у перегляді всієї управлінської діяльності підприємства. Адже, управлінська діяльність на сьогоднішній день $\epsilon$ одним із найголовніших факторів ефективного функціонування підприємства чи компанії, а формування дієвого організаційно-економічного механізму управління сприятиме продуктивному управлінню та забезпеченню високого рівня конкурентоспроможності [7].

До ключових методів організаційно-економічного управління конкурентоспроможністю сучасного підприємства необхідно віднести [8]:

- пожвавлення інвестиційної та інноваційної діяльності, технічне переозброєння;

- покращення управління в сфері фінансів та капітальних вкладень;

- розроблення заходів щодо продуктивного використання виробничих, матеріальних та фінансових ресурсів;

$$
\text { - покращення системи }
$$

управління кадрами та мотивацією персоналу;

- запровадження дієвої системи управління якістю;

\section{- використання}

методик

управління якісними показниками виробів чи послуг;

- зміна підходів до планування та диверсифікації виробничого процесу;

- перегляд системи обліку та аналізу витрат;

- покращення маркетингових досліджень за рахунок перегляду підходів до вивчення ринку;

- покращення інформаційного забезпечення та цифровізація всіх можливих управлінських, організаційних та виробничих процесів;

- сполучення всіх складових управлінської діяльності відносно внутрішньої та зовнішньої політики підприємства.

Отже, стосовно організаційноекономічного механізму управління діяльністю підприємств залізничного транспорту, то економічна частина його складається не лише 3 певних методів управління, але й розкриває основні цілі їх діяльності для досягнення конкурентоспроможності на ринку транспортних послуг [9]. Відносно організаційної складової, то вона не 
обмежується лише організаційними методами управління, а включає організаційно-структурні, соціальнопсихологічні та адміністративні підходи.

Як і кожну управлінську систему, організаційно-економічний механізм управління діяльністю підприємствами залізничного транспорту формують дві підсистеми - керуюча та керована, що маю між собою складний діалектичний зв'язок. Для залізничного господарства в ролі керованої підсистеми виступають служби, лінійні підрозділи та підприємства галузі. А сутність і будова керуючої підсистеми є основою механізму управління та визначає основні цілій i завдання управління. Функції управління виконує організаційна структура, котра приводить до ладу весь управлінський процес, впорядковує взаємодію всіх підрозділів та господарств, розподіляє відповідальність та встановлює порядок підпорядкування.

Важливу роль в організаційноекономічному механізмі управління діяльністю підприємств транспортної сфери, в тому числі й залізничного транспорту, для утримання наявних конкурентних переваг та отримання нових відіграє інструментарій його виконання. Потрібно відзначити, що головна мета інструментарію заключається в забезпечення таких організаційноекономічних умов, які сприятимуть виконанню всіх поставлених завдань перед підприємствами залізничного транспорту (рис. 1).

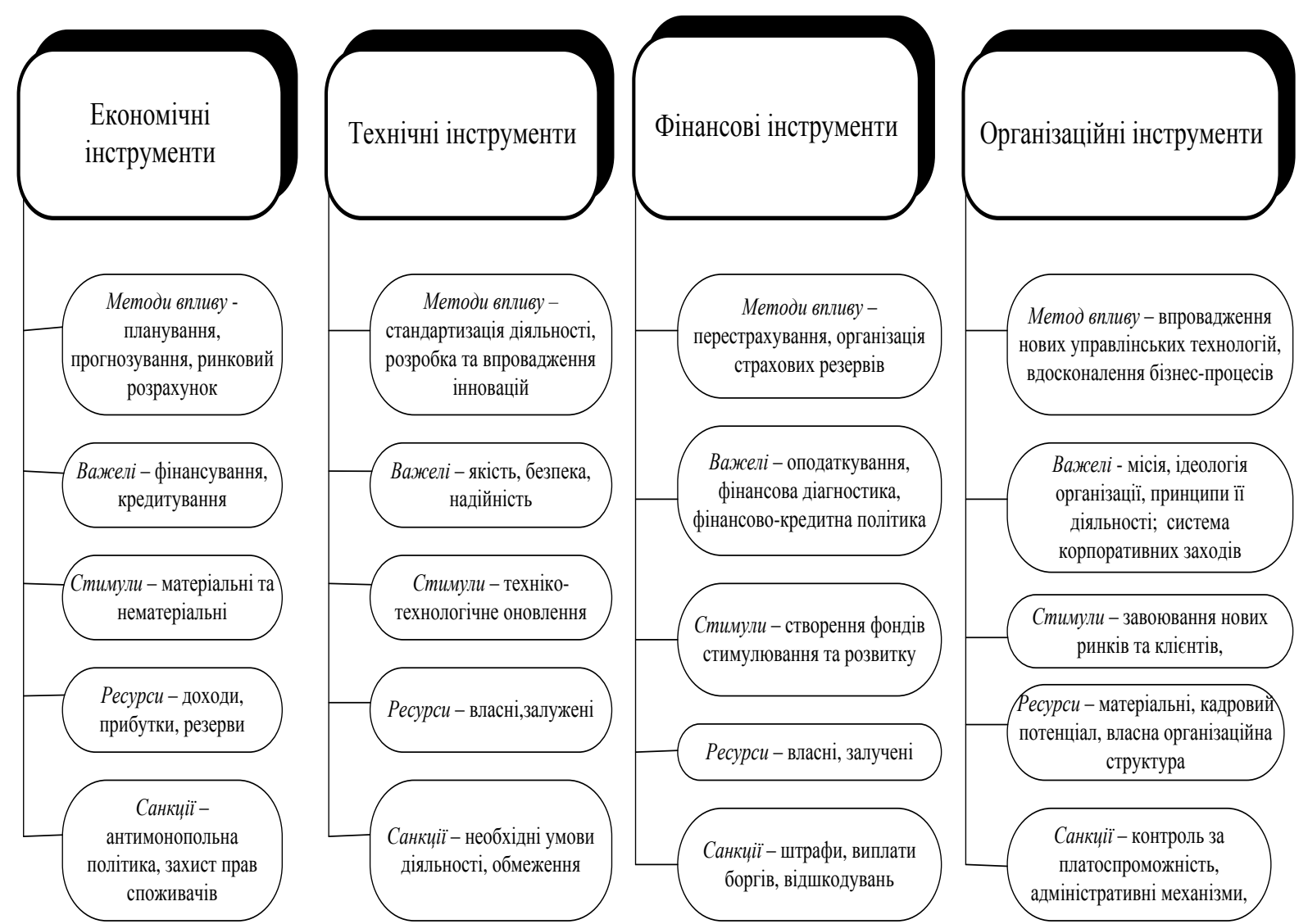

Рис. 1. Інструментарій забезпечення виконання організаційно-економічного механізму управління конкурентними перевагами підприємств залізничного транспорту

3 рис. 1, на котрому зображено основні інструменти забезпечення дієвого функціонування організаційноекономічного механізму управління конкурентними перевагами підприємств залізничного транспорту, видно що 
забезпечення їх конкурентоспроможності $\epsilon$ сукупним результатом тісної взаємодії всіх складових організаційного, фінансового, технічного та економічного інструментарію.

Отже, метою формування управління підприємствами залізничного транспорту (рис. 2) є формування сприятливих організаційних та економічних умов для забезпечення конкурентоспроможності на ринку транспортних послуг. організаційного-економічного механізму

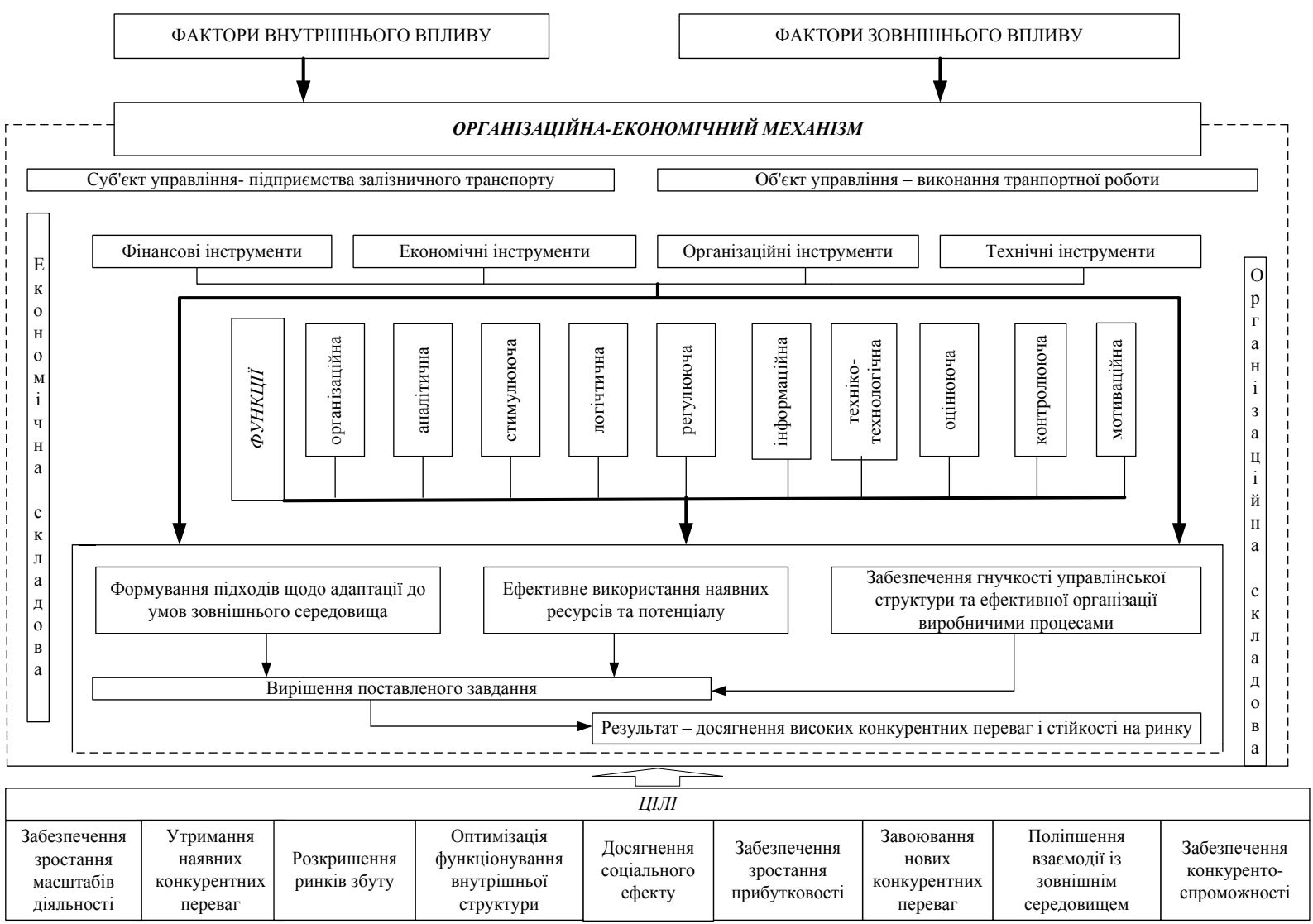

Рис. 2. Організачійно-економічний механізм управління конкурентоспроможність підприємств залізничного транспорту

Як видно з рисунка 2, структура ключових елементів запропонованого механізму управління конкурентними перевагами підприємств залізничного транспорту сформована на основі програмно-цільових блоків, котрі відображають потрібні дії, взаємозалежність організаційних, технічних, економічних заходів, для результативної реалізації управлінських рішень в сфері транспорту.

Таким чином, при формуванні організаційно-економічного механізму забезпечення конкурентоспроможності підприємств залізничного транспорту важливе значення має поєднання організаційної та економічної складових, що дозволяе галузі набути певних конкурентних переваг для забезпечення конкурентоспроможності [10].

Також, важливе значення має формування підходів ефективного управління в межах забезпечення конкурентоспроможності підприємств залізничної галузі, що стануть у нагоді керівництву залізниць для адаптації управлінських рішень до сучасних умов ведення економічної діяльності: 
- розроблення конкурентних стратегій та цілей розвитку галузі для визначення заходів спрямованих на збільшення рівня динамічності та сприйняття внутрішньою структурою ринкових змін;

- активізація

потенціалу підприємств галузі;

- використання комплексного

підходу для розроблення всіх видів планів розвитку підприємств залізничного транспорту 3 метою підвищення рівня конкурентних переваг, активному функціонуванні на ринку, забезпечення продуктивної та беззбиткової діяльності галузі;

- вдосконалення кадрової політики та системи мотивації за рахунок перепідготовки персоналу, вдосконалення мотивації, забезпечення соціального захисту, тощо;

- удосконалення системи якості

для забезпечення конкурентоспроможності за рахунок формування нового підходу для досягнення конкурентних переваг на ринку перевезень вантажів та пасажирів;

- оптимізація обліково-фінансової політики та інші заходи.

$$
\text { Отже, }
$$

запровадження організаційно-економічного механізму управління конкурентоспроможність підприємств залізничного транспорту дає змогу керівництву галузі своєчасно вносити корективи в стратегічні плани, порівняти та аналізувати певні показники, рівень їх виконання відповідно до встановлених строків та нормативним прогнозам.

Висновки. Економічні труднощі, сучасне важке становище підприємств залізничного транспорту, ускладнене посилення конкурентної боротьби призводить до необхідності своєчасно реагувати на всі ринкові виклики шляхом формування механізму організаційноекономічного управління. Тож, для забезпечення конкурентоспроможності сучасне підприємство має швидко реагувати на зміни та невизначеність зовнішнього середовища, а сучасний підхід до його організаційної діяльності має базуватися на сполученні людських цінностей, управлінських змін та постійної адаптації до мінливого зовнішнього середовища.

Запропоновані

підходи

впровадження управлінського механізму для забезпечення конкурентоспроможності підприємств залізничного транспорту дають змогу утримати їх наявні конкуренті позиції та підвищувати рівень своєї конкурентоспроможності сьогодні та в майбутньому. Але заходи, спрямовані на збільшення рівня конкурентоспроможності не будуть виконані, якщо керівництво залізничної галузі чітко не визначить стратегію розвитку кожної складової ланки залізничного транспорту як поточному періоді, так і на перспективу.

\section{ПЕРЕЛІК ВИКОРИСТАНИХ ДЖЕРЕЛ}

1. Данько M.I. Забезпечення конкурентоспроможності промислових підприємств в умовах міжнародних транспортних коридорів: монографія/ M.I. Данько, В.Л. Дикань, Н.В. Якименко. - . Х.: УкрДАЗТ, 2008. - 194 с.

2. Ейтутіс Д.Г. К Конкурентоспроможність регіональних залізниць / Д. Г. Ейтутіс// Залізничний транспорт України. - 2007.- №3. - С. 90-92.

3. Гандельсман Т. А. Конкуренция на рынке железнодорожных перевозок / T. А. Гандельсман // Экономика железных дорог. - 2009. - № 3. - С. 9 - 13 .

4. Бараш Ю. С. Управління конкурентоспроможністю залізничних пасажирських перевезень: монографія / Ю. С. Бараш, Т. Ю. Чаркіна. - Д.: ДНУЗТ, 2015. - $184 \mathrm{c}$.

5. Обруч Г. В. Теоретичні аспекти підвищення конкурентоспроможності вагонобудівних підприємств України / Г. В. Обруч // Вісник економіки транспорту і промисловості. - 2015. - № 52. - С. 67-73. 
6. Каличева Н.С. Підходи до управління конкурентними перевагами підприємств залізничного транспорту/ Н.Є. Каличева// Причорноморські економічні студії: науковий журнал. - Одеса, Причорноморський науково-дослідний інститут економіки та інновацій. -2017. - Вип. 21. - C. 86-91

7. Дикань В.Л. Реформирование экономики Украины и конкурентоустойчивость предприятий: монографія/ В.Л. Дикань. - Харьков: Основа, 1997. $-345 \mathrm{c} /$

8. Должанський I.3. Конкурентоспроможність підприємства: навчальний посібник/ І.3. Должанський, Т.О. Загорна. Київ: Центр навчальної літератури, 2006. $384 \mathrm{c}$.

9. Каличева Н.С. Методологічні аспекти підвищення конкурентоспроможності підприємств залізничного транспорту за рахунок управління конкурентними позиціями/ Н.С. Каличева// Науковий вісник Херсонського державного університету. Серія: Економічні науки. - Херсон, 2017. Вип. 27. - Ч. 1. С. $139-142$

10. Токмакова I. В. Забезпечення гармонійного розвитку залізничного транспорту України: монографія / I.В. Токмакова. - Харків: УкрДУЗТ, 2015. $403 \mathrm{c}$.

\section{REFERENCES}

1. Danko M.I., Dikan V.L., Yakimenko N.V. (2008) Zabezpechennja konkurentospromozhnosti promyslovykh pidpryjemstv $v$ umovakh mizhnarodnykh transportnykh korydoriv: monoghrafija [Ensuring the competitiveness of industrial enterprises in the context of international transport corridors: a monograph]. Kh.: Ukrainian State Academy of Railway Transport. (in Ukrainian)

$$
\text { 2. Eytutis D.G. (2007) }
$$

Konkurentospromozhnistj reghionaljnykh zaliznycj [Competitiveness of regional railways]. Railway transport of Ukraine, No3, pp. 90-92.

$$
\text { 3. Gandelsman T.A. (2009) }
$$

Konkurentsiya na rynke zheleznodorozhnykh perevozok [Competition in the rail market]. Railway Economy. No3, pp. 9 - 13 .
4. Barash Yu. S., Charkina T. Yu. (2015)

Upravlinnja

konkurentospromozhnistju zaliznychnykh pasazhyrsjkykh perevezenj: monoghrafija [Management of Competitiveness of Rail Passenger Transportation: Monograph]. D: DNUZT. (in Ukrainian)

5. Obruch H. V. (2015) Teoretychni aspekty pidvyshhennja konkurentospromozhnosti vaghonobudivnykh pidpryjemstv Ukrajiny [Theoretical aspects of increasing competitiveness of Ukrainian car-building enterprises]. The bulletin of Transport and Industry Economics. No 52, pp. 67-73.

6. Kalicheva N.E. (2017) Pidkhody do upravlinnja konkurentnymy perevaghamy pidpryjemstv zaliznychnogho transportu [Approaches to managing the competitive advantages of rail transport enterprises]. Black Sea Economic Studies: Scientific Journal. Vol 21, pp. $86-91$

7. Dykan V.L. (1997) Reformirovanie ekonomiki Ukrainy i konkurentoustoychivost' predpriyatiy: monografiya [Reforming the economy of Ukraine and the competitiveness of enterprises: monographs]. Kharkiv: Basis. (in Ukrainian)

8. Dolgazkiy I. Z., Zagorn T.O. (2006) Konkurentospromozhnistj pidpryjemstva: navchaljnyj posibnyk [The competitiveness of the enterprise: Tutorial]. Kyiv: Center for Educational Literature. (in Ukrainian)

$$
\text { 9. Kalicheva N.E. }
$$

Metodologhichni aspekty pidvyshhennja konkurentospromozhnosti pidpryjemstv zaliznychnogho transportu za rakhunok upravlinnja konkurentnymy pozycijamy [Methodological aspects of increasing the competitiveness of railway companies through the management of competitive positions]. Scientific Herald of Kherson State University. Series: Economic Sciences. Vol. 27. No 1, pp. $139-142$

10. Tokmakova I.V.

Zabezpechennja gharmonijnogho rozvytku zaliznychnogho transportu Ukrajiny: monoghrafija [Ensuring the harmonious development of rail transport in Ukraine: a monograph] / I. B. Токмакова. - Kharkiv: Ukrainian State University of Railway Transport. (in Ukrainian) 